\title{
Government action needed to mitigate 'greenhouse effect'
}

\section{London}

THIs week is a busy one for researchers, environmentalists and policy-makers concerned with the predicted increase in global temperatures as a result of the 'greenhouse effect'. In Geneva, the intergovernmental panel on climate change set up by the World Meteorological Organisation and the United Nations Environment Programme (UNEP) meets for the first time; its remit is to evaluate current scientific knowledge on the subject, determine to what extent climate change can be slowed down and formulate policies to adapt national economies as necessary. And a conference in Hamburg - billed as the follow-up to the Toronto conference on the changing atmosphere held in June (see Nature 333, 691; 1988) is planning to formulate policies to tackle the problems of the 'greenhouse effect', acid rain and the destruction of the ozone layer. This action plan has already been dubbed the 'Hamburg Manifesto'.

The scientific evidence presented at both events will include a comprehensive global study of the effects of climatic variations on agriculture. This study, made available last week, was carried out for the International Institute for Applied Systems Analysis and UNEP, under the direction of Martin Parry of the University of Birmingham. The work was carried out over a period of four years by a team of 76 researchers from 50 institutions in 17 countries.

It covers not only the effects of shortand long-term climatic variations on agricultural productivity, but also the effect on regional and national economies. And it considers possible adjustments to mitigate these effects. Parry urges that such adjustments must be made in advance of changing conditions rather than as a response to them.

The scenario for climate change in the long term is based on a possible increase in global mean temperature of $1.5-5.5 \%$ between the years 2050 and 2100 ; the temperatures are derived from the Goddard Institute for Space Studies general circulation model.

Five areas in the cool temperate and cold regions of the world were studied: Saskatchewan (Canada), Iceland, Finland, the northern European Soviet Union and Japan. The results of the Saskatchewan study indicate that a temperature increase could have a disastrous effect on the prairie wheatbelt of the United States and Canada. This area could return to the 'dustbowl' conditions of the 1930s, with severe droughts occurring more frequently. A dramatic setback in farm production could lead to the loss of about 4,000 jobs and a loss in income of about Can $\$ 500$ million annually.

The outlook for the Soviet Union in the areas studied is less grim. Climate warming could improve crop yields significantly if crops more suited to the warmer climate were grown, although, in the long term, increased precipitation in the western region, around Leningrad, could lead to declining crop yields, because of soil degradation and waterlogging of fields.

The problem for Japan will be different: a temperature rise will favour increased production of rice leading to an acute surplus. The price of rice, grown on four million farms, is determined by the government and in recent years has been three to four times higher than world prices. A significant increase in production would require a change in traditional government policies towards minimized intervention and a liberalized rice market, says the report.

Agricultural policies in northern Europe might also need some reconsideration: the studies of Finland and Iceland indicate that increased crop yields in northern Europe will exacerbate current problems with expensive agricultural policies that subsidize farm production and exports of surplus products.

At lower latitudes, where most of the semi-arid areas studied are located, a temperature increase resulting from the greenhouse effect is expected to be signficantly smaller than at middle and high latitudes. And there are still great uncertainties in estimates of changes in precipitation, which is of great importance in these regions. So researchers focused on short-term climatic variations, especially droughts.

The areas studied were central and eastern Kenya, northeast Brazil, the central sierra of Ecuador, dry tropical India, the Stavropol territory and Aratov regions of the Soviet Union and the Australian wheatbelt. Among the outcomes of the studies was the prediction that the El Niño phenomenon which was linked in 1982-83 with disastrous droughts in semi-arid regions of Brazil, Australia, India and parts of Africa may become more frequent. And severe shocks to agriculture from floods, persistent droughts, soil erosion, forest fires and crop pests may become more intense. Recommendations made include better use of land, resources and of new technology in order to increase agricultural production and the development of a consistent set of draught policies.

This work is being followed up by similar studies for Europe and South-East Asia.

Christine McGourty
More money for science in Ireland Dublin

IRELAND plans to spend three times as much on science and technology next year as this, despite continuing reductions of general expenditure. Estimates released on 25 October show an increase from IR£3.1 million to IR£8.2 milion for science and technology, while general spending is to fall by IR£224 million.

The Minister for Science and Technology, Dr Sean McCarthy, said that the increase reflects the government's commitment to "investing in the people who can design new products . . . research new opportunities and apply science and technology to new areas of development".

The largest allocation of funds (IR£2.25 million) is to the national biotechnology programme. Two further biotechnology centres will be set up at Trinity College, Dublin, and University College, Dublin. Last year, the programme, which began in 1987, received IR£1.5 million and set up three centres of excellence, in diagnostics, cell culture and food technology.

Despite the increased budget, grants to colleges will fall by $1-3$ per cent, and research grants and fellowships to the universities will fall by over 10 per cent, leaving scientists to compete even more intensely for the limited pool of contract funding available. Mary Mulvihill

\section{Steps towards a new science policy}

\section{Barcelona}

$\mathrm{ON}_{\mathrm{N}}$ his return from the Seoul Olympics, where he was representing the Spanish government, the Minister for Education and Science unexpectedly reshuffled some of the main science policy offices. Dr Emilio Muñoz, secretary general of the National Plan for Research, has been appointed president of the science research council (CSIC), he in turn was replaced by Dr Luis Oro, formerly director general of science policy, a position now taken by Dr Pedro Ripoll, a geneticist from the Centro de Biología Molecular in Madrid.

The extent of the changes came as a surprise. Most of those previously involved in the direction of CSIC will leave their posts and will be replaced by former colleagues of Muñoz in the national plan. Thus two of the principal institutions in Spanish research will see major changes in their senior positions. These changes will deeply affect the conduct of research policy in the coming years.

Muñoz, a molecular biologist from the CSIC, says he will try to improve CSIC's relations with universities and with private industry, two key issues just now.

Pedro Puigdoménech 